\title{
An Approach to Assess Relative Degradation in Dissimilar Forests: Toward a Comparative Assessment of Institutional Outcomes
}

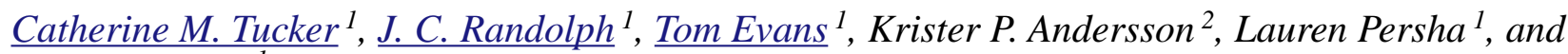 \\ Glen M. Green ${ }^{1}$
}

\begin{abstract}
A significant challenge in the assessment of forest management outcomes is the limited ability to compare forest conditions quantitatively across ecological zones. We propose an approach for comparing different forest types through the use of reference forests. We tested our idea by drawing a sample of 42 forests from the Midwest USA, Mexico, Guatemala, Honduras, Brazil, Bolivia, Uganda, and Nepal. We grouped these forests by shared characteristics and selected a reference forest to serve as a baseline for each forest type. We developed an index of disturbances using ratios of several forest measurements to assess differences between each study forest and its reference forest. None of the study forests was known to have been impacted by major natural disturbances during the past 50 years. Therefore, the disturbances in these forests appear to be largely related to human activities. The forests most similar to their reference forests have had limited human interventions. Our results indicate the potential of this approach to compare different forest conditions across biomes. We argue that development of this approach could facilitate analyses of forest management institutions, promote reliable indicators to compare management outcomes, and contribute to improved policies for conservation.
\end{abstract}

Key Words: biophysical factors; comparative analysis; forest management; institutions; multidisciplinary methodology; reference forests

\section{INTRODUCTION}

Numerous case studies have evaluated forest management institutions, from scientific management plans and conservation methods to indigenous and community forestry approaches (e.g., Alcorn 1990 , Gibson et al. 2000, Tucker 2004b, Brosius et al. 2005, Haenn 2005, Andersson and Gibson 2007). Although these studies have made valuable contributions to our understanding of institutional arrangements that appear to encourage, or inhibit, conservation of forest resources, their limited focus constrains their ability to provide generalizable recommendations. In particular, individual case studies cannot address a growing need in forest conservation and policy design: a rigorous, comparative assessment of the various institutional options and associated outcomes that exist around the world. Comparative studies of institutional arrangements for forest management and conservation across different biomes are becoming more common, but they remain exceptions (e.g.,
Banana and Gombya-Ssembajjwe 2000, Bruner et al. 2001, Gibson et al. 2002). They share a common difficulty of not controlling for biophysical factors that can greatly influence forest change processes. Such studies may credit, or blame, institutional arrangements and conservation efforts for outcomes that actually were shaped by underlying biophysical factors.

A challenge in the study of human impacts is to understand what social, economic, and institutional factors lead to particular environmental outcomes. In aquatic and atmospheric systems, some measures are broadly comparable across locations. Water quality and quantity statistics in one location have the same meaning in another location. This is not true for forest ecosystems, because global variations in climate, soil, and geology result in different forest types. Thus, forest mensuration values for a particular forest may represent a mature and healthy forest in one location but a highly degraded forest in another. 
Rigorous analyses of the various approaches to manage, restore, and conserve forests require comparable, quantitative measures to assess forest conditions across ecological zones. This is particularly necessary because many conservation policies and management approaches are defined and implemented from the top down, across diverse ecological and social systems. Although many researchers correctly note that management and conservation strategies should be site specific, that is not the worldwide reality. Even if it were the case, it would be useful to compare outcomes to discover whether certain institutional arrangements are more likely than others to result in more sustainable management of forest resources. For example, debates continue over whether, and what types of, protected areas are successful in conserving forests. National governments tend to adopt several popular approaches without consideration of intranational ecological variation. Competing paradigms for protected areas include attempts to exclude human presence, allow limited uses, or permit wideranging interventions (IUCN/World Conservation Union 1994, Phillips 2004). Researchers tend to focus on studies of single cases or a few cases to reach conclusions as to efficacy. Evidence exists for success and failure of all arrangements, with limited or contradictory assessments regarding what factors are most significant for the outcomes across sites.

It is vital to control for biophysical variation if we are to distinguish the effects due to variability in biophysical factors from those of forest management institutions. Only through such a comparative method can we move toward more objective assessments of management strategies (e. g., community, collaborative, private, governmentmanaged, product-specific restricted harvesting, no-use) and associated institutional arrangements that are best suited to specific contexts. This is particularly relevant for regions experiencing rapid transformations, where implementation of inefficient or inappropriate institutions could lead to the demise of endangered resources.

Comparing forest management institutions and results across different ecological zones is a challenge. Forests can differ immensely in biophysical conditions: a degraded tropical wet forest could have more biomass, a larger basal area, and greater species richness than a conserved, wellmanaged, dry pine (Pinus spp.) forest. Thus, typical forest measurements must be used cautiously when comparing forests across contrasting climatic, edaphic, and vegetative conditions. Although numerous studies have evaluated forest characteristics and management under similar biophysical conditions (e.g., Uuttera et al. 1996, 2000, Lawesson et al. 1998, McClenahen and Houston 1998, Bugmann 2001, Ni 2004; Andersson and Pacheco 2006), appraisal of forest management outcomes across different biophysical conditions has been constrained by a limited ability to use quantitative analyses (i.e., Hockings 2003, Kobayashi 2004). Systematic methods of measurement must be developed in order to assess conservation efforts comparatively (Walters 1997, Saterson et al. 2004).

We seek to meet this challenge by proposing a methodology to compare forests across ecological zones and geographic locations based on replicable, reliable information. Our approach combines systematic measurement of certain biophysical dimensions of forests and an estimation of the degree to which these dimensions differ from comparable reference forests. We employ three criteria: (1) Validity of data: Do indicators measure changing forest conditions? This requires the inclusion of biophysical information and indicators that measure human efforts to manage the forest resource. (2) Reliability: Do indicators objectively measure forest conditions? Rather than rely on the opinions of resource users or experts, our approach uses direct ecological measurements as the basis for our forest condition indicators, hence the measures are more consistent over time and across space than measures that rely on human opinions. (3) Data availability: Are the data needed to develop indicators available at a reasonable cost? We rely upon existing databases of forest mensuration data and corroborating observations from site visits.

In addition to the biophysical factors that must be assessed in order to establish a comparative framework for analysis of forest conditions, human activity through time represents a major influence on the landscape and impacts forests. This paper focuses on the biophysical environment and the importance of quantitative assessments to develop a rigorous comparative method for assessing forest conditions. We aim for this method to facilitate the evaluation of human impacts and institutional outcomes in forests. We selected 42 forests representing wet tropical, dry tropical, and temperate forests for our analysis. The forest selection was based on the availability of extensive and comparable data for each of these sites, as discussed below. 
We first review the fundamental concepts in our approach: (1) biophysical environment, (2) forest conditions, and (3) institutional and social dimensions. Then we present the methods used to select and assess study forests, identify reference forests, and develop a measure of difference. This methodology represents one possible approach to control for biophysical variations in order to compare institutional arrangements and management outcomes across forests. We examine the results and discuss how this approach may facilitate distinguishing the effects of biophysical constraints from human-related interventions on forest conditions. Although this method entails several shortcomings, which we address, we aim to stimulate constructive discussion. We conclude by discussing potential policy applications and broader implications.

\section{Biophysical Environment}

Climate, topography, soils, and vegetation interact to produce regional-scale patterns of distinguishable terrestrial ecosystems. Many biophysical factors influence forests, and their interactions and influence vary across space and time. Patterns in vegetation would occur even in the complete absence of humans. Biogeographers, ecologists, climatologists, soil scientists, and others have explored these relationships for decades and produced various approaches for presenting them (e.g., Holdridge 1947, 1967, Whittaker 1975).

Annual mean temperature and annual mean precipitation have produced consistently meaningful relationships with terrestrial vegetation types; therefore, we rely on these as principal variables for classifying forest types. These climatic factors often are combined in the terms (1) actual evapotranspiration (AET), which is the annual sum of the water evaporated to the atmosphere from soil and other surfaces plus the water transpired by plants, and (2) potential evapotranspiration (PET), which is the amount of evapotranspiration that would occur with unlimited water availability.

Our approach, which draws on the well-recognized schema developed by researchers such as Holdridge (1947, 1967) and Whittaker (1975), nevertheless makes certain assumptions. By not incorporating details such as rainfall seasonality, wind speed, or humidity data, they assume that temperature and precipitation exhibit systematic variation on an annual basis. That assumption is overly simplistic for tropical regions. Additionally, by using averages rather than extremes, their methods may not incorporate the disproportionately potent effects of extremes in determining vegetation characteristics and may mask important influences such as the frequency, intensity, and duration of dry periods.

However, more complex forest classification systems for the tropics, such as one based on a perhumidity index, require substantially more data than were available for our study. Even with more complete datasets, the complex relationships among climatic and non-climatic factors prohibit the development of a precise classification system for tropical forest types that is applicable on a global scale (Richards 1996). Recognizing these constraints, we use Whittaker's schema (1975) as a reference, making adjustments based on our fieldwork to account for conditions that vary from his assumptions.

Most climatically based forest classification systems do not include the influence of soils, although more recent approaches (e.g., Aber and Melillo 2001) do incorporate soil types. Soils interact with climate to influence forest species composition and productivity. Moreover, human activities such as agriculture and livestock grazing can affect soils over time. Thus, we also use soil data in our efforts to control for variations in biophysical conditions.

\section{Forest Conditions}

The term "forest conditions" has been used in scientific literature for over a century (Whitford 1901) and has categorized or described the generalized state of a forest with regard to its "sustainability, productivity, aesthetics, contamination, utilization, diversity, and extent" (Riitters et al. 1992:22). The term also has been used in reference to a variety of disturbances such as fire (Miller and Urban 2000), acidic deposition (Loucks 1992, Reams and Peterson 1992), and pollution (Kubin et al. 2000, Nordlund 2000). It is occasionally used as a synonym for describing forest health (Ferretti et al. 1999, McLaughlin and Percy 1999, Gorte 2002).

Although most definitions of forest conditions have been ambiguous (Skelly 1989), several examples exist of studies and programs designed to examine forest conditions. Lundquist and Beatty (1999) state 
that forest conditions are assessed by comparing the current ecological state to a range of values specified for a number of variables. Unfortunately, there is no consensus concerning which variables should be examined, how they should be examined, and at what temporal/spatial frequency and intensity. Consequently, we developed a set of "most useful" variables in providing a quantitative assessment of forest conditions. These variables were selected based on a number of forest studies and prior research that identified them as reliable measures (Randolph et al. 2005). These include total basal area of all woody species in the forest, and for each tree species: the basal areas of mature trees and saplings, mean tree density, and mean diameter at breast height (dbh) of tree trunks. Additional data about the topography, climate, and physical and chemical properties of the soil for each forested site are also considered to better understand the vegetation data. These measures of forests and a disturbance index are discussed in more detail below. In a companion article, we further explore the challenges of evaluating forest conditions, and argue for the complementarity of quantitative and qualitative methods (Persha et al. 2005).

\section{Institutional and Social Dimensions of Forest Conditions}

The eventual goal of this research is to improve the ability to assess forest management institutions that promote conservation. We define "institutions" as the formal and informal rules that guide what a person may, must, and must not do (Ostrom et al. 2002). Although we do not focus on institutions in this article, our rationale for developing this approach arises from a concern to distinguish biophysical factors from institutional and other social impacts on forests. We broadly conceive of institutions as human responses to the existing biophysical environment and socioeconomic contexts. As such, institutions can exist at different levels of social aggregation: international (treaties, protocols, and frameworks), national (policies, rules, and regulations), or local (community bylaws, norms, and practices). Much recent work on natural resource management considers how institutional arrangements, in conjunction with political, technological, and social factors, may influence land-cover transformations (e.g., Bromley 1992, Gibson et al. 2000, Young 2002, Andersson 2003, Dietz et al. 2003, Ostrom 2005, Tucker and Ostrom 2005). We further recognize that institutions and forest conditions are fundamentally shaped by social contexts. Patterns of resource appropriation and associated institutions emerge and operate within complex political, economic, sociocultural, and demographic processes, and reflect the peoples' understandings and belief systems (Toledo 2001). Forest-use decisions and uses relate to historical as well as current pressures and incentives experienced by human populations. Earth's remaining forests reflect thousands of years of human influence (Williams 2003), although the severity of human impacts varies widely. Thus forest conditions reflect ongoing, direct, and indirect human interactions with forests and associated biophysical processes.

\section{METHODS}

\section{Study Forests}

Study forests were selected from the data base of the International Forestry Resources and Institutions (IFRI) Research Network. The network, which consists of 13 collaborating research centers in 11 countries in Africa, Asia, North America, and Latin America, seeks to address why some rural communities are more successful in managing their forest resources than others (Ostrom and Wertime 2000). To answer this question, IFRI researchers follow a uniform set of research protocols to examine demographic, biophysical, institutional, socioeconomic, and political dimensions of forest users and forest characteristics, making the collected data suitable for comparative cross-site analysis.

As of December 2006, the IFRI database included community-level data for 202 sites and 270 forests. From the IFRI database, we selected forests that met these criteria: (1) at least one of us had studied the forest, (2) remotely sensed images and GIS coverages were available to provide supplementary data, (3) data from a suitable reference forest existed, and (4) the forest data were accompanied by relevant demographic, institutional, and socioeconomic data. These criteria were selected not only for this analysis, but in anticipation of subsequent analyses to address interrelationships among land-cover change and institutional arrangements. We selected 42 forests in six regions, including eastern Bolivia, eastern Brazil, Mesoamerica, central Nepal, southern Uganda, and the Midwest USA. 
We examined plot data from three to 14 study forests within each region and compared the data among study sites within each forest and between study forests, and matched reference forests. Our forest data for each site included total basal area, basal area by species for trees $(\mathrm{dbh}>10 \mathrm{~cm})$, basal area by species for saplings $(\mathrm{dbh}>2.5 \mathrm{~cm}<10 \mathrm{~cm})$, tree density, sapling density, mean tree dbh, mean tree height, and number of tree species observed.

Forest plots were $300 \mathrm{~m}^{2}$ and had been located in each forest using a random-sampling procedure. The number of plots measured per forest ranged from a minimum of five to a maximum of 76 , with an overall average of 26.7. The number of plots sampled in each forest relates primarily to the species richness and range of variation. In forests with low species richness, minimal topographic variation, and fairly consistent histories of use and exploitation throughout the forest, fewer plots are required to obtain a representative estimate of key variables.

\section{Reference Forests}

Central to our analysis is the concept of reference forests, which are old-growth forests, within a given climatic zone and biome type, known to have remained relatively undisturbed by natural and human influences. We recognize that these reference forests, like all natural ecosystems, continue to experience change at varying temporal and spatial extents and that all forests are dynamic systems influenced by multiple factors. We also recognize that few, if any, locations on Earth have not been affected by humans directly or indirectly at one time or another. Reference forests should not be considered "pristine" nor in equilibrium or "climax," but rather as baselines with a set of forest conditions that can be used for comparison to other forests. Although detailed historical records are scant for most of our reference forests, existing data indicate that they have remained relatively undisturbed by human and natural perturbations through the last half century and probably much longer. Therefore, they represent suitable references with which to evaluate forests that have experienced greater interventions.

The use of reference forests (and other reference ecosystem approaches) is recognized as a way to provide a baseline or controlled comparison for studies of sites subject to human interventions
(Frelich et al. 2005). In many cases, it can be difficult to identify suitable reference information (Asbjornsen et al. 2005, Kenefic et al. 2005), and Saterson et al. (2004) note that it is often necessary to rely on static measures, and derived indices, to assess dynamic natural and social systems. Therefore, the selection of our study forests included the criterion that there was an appropriate reference forest for comparison.

We estimate the extent to which each study forest differs from a comparable reference forest, and use those comparisons as a replicable way of comparing forest conditions. Any discernible differences between the forest conditions in study forests and their reference forests, we attribute to human interventions. Because we have conducted fieldwork in the forests in our sample and have collected available historical data, we can be confident that natural disasters have not played a recent role in the conditions of these forests. Thus, the procedure allows us to compare a range of forests and approximate the comparative extent of human influence.

Almost all of the reference forests we used are from the data base collected by Alwyn Gentry over a period of about 20 years (Phillips and Miller 2002, the Spatial Analysis of Local Vegetation Indices Across Scales (SALVIAS) Project 2003). Gentry used multiple 0.1 -ha transects to obtain quantitative forest data in carefully selected, undisturbed forests representing a wide range of forest types. Gentry selected each forest to be inventoried after extensive interviews in each region to ensure that these forests had experienced minimal human influence. He inventoried a total of 212 forests in 40 countries, although most of his data are from the Western Hemisphere (Gentry 1992, Phillips et al. 1994). Gentry's methods are described in detail by Phillips and Miller (2002), and the complete data base is available upon request. In Nepal and Uganda, where Gentry did not make measurements, we consulted with scholars and foresters in the region to identify mature, undisturbed forests with forest mensuration data comparable to those of Gentry.

\section{Climate}

To examine climatic differences among our study and reference forests, and to gain a fairly detailed climate dataset for all locations, we acquired global datasets for temperature and precipitation from the 
University of Delaware Center for Climatic Research website (Willmott and Matsuura 2004). These data are aggregated from monthly time-series data of 1950-1999, compiled from global climate stations and interpolated to produce gridded data at a resolution of $0.5^{\circ}$ latitude $\times 0.5^{\circ}$ longitude (Willmott and Feddema 1992, Willmott and Matsuura 1995, Willmott and Robeson 1995). The station coverage in more remote areas is relatively sparse and influences the accuracy of the interpolated values, but the accuracy can be increased by accounting for the elevations of stations (Willmott and Matsuura 1995). The adjusted station data were interpolated to produce a global dataset; then each grid cell value was adjusted according to the average lapse rate. Thus, the interpolated cell values to some degree control for differences in elevation as derived from coarsescale DEM data. However, given the coarse scale of the DEM used in this process, grid cells with significant within-cell elevation variability may misrepresent the actual temperature regime for all areas in the cell. The precipitation data were interpolated without the elevation factor adjustment. When meteorological stations with extensive, reliable records existed at or near our sites, data from those stations were used.

We estimated PET with the Thornthwaite-Mather method (Thornthwaite 1948, Thornthwaite and Mather 1955, 1957, Mather 1978), which uses mean monthly precipitation and temperature data and is adjusted for seasonality and latitude. This method provides a relatively straightforward way for linking local climates to vegetation. The precision of PET calculations can be increased by using more refined methods, such as those developed by Penman (1948), which recognize the role of humidity, wind speed, and radiation on evapotranspiration characteristics. However, those more complex equations require additional field data that were unavailable for this study.

The forest types we studied include wet tropical forests, dry tropical forests, and temperate forests, with each forest type having a typical range of PET values (Aber and Melillo 2001), although orographic effects can produce significant differences locally. Wet tropical forests have high PET values, typically 1400 to $2200 \mathrm{~mm}$ of water per year. In climates where precipitation is abundant, the AET value is the same as the PET value. Wet tropical forests have abundant precipitation and solar radiation, resulting in year-long growing seasons with little or no water stress on vegetation. Broadleaf evergreen trees typically dominate these forests. In dry tropical forests, PET values typically are 800 to $1400 \mathrm{~mm}$ and AET is $70 \%$ to $90 \%$ of PET, usually with a pronounced dry season. Both coniferous and broadleaf trees occur in these forests. In wet temperate forests, AET and PET are similar, but less solar radiation and cooler temperatures reduce evaporation, and PET is lower at 700 to 800 $\mathrm{mm}$. Coniferous trees typically dominate these forests. In dry temperate forests, PET values are 600 to $800 \mathrm{~mm}$ with AET about $90 \%$ of PET. Within this range, higher values result in deciduous forests, whereas coniferous forests typically occur at lower values.

Our analysis examined climate data for each study forest and the corresponding reference forest in each region (Fig. 1). There is relatively little variation in annual temperatures and annual precipitation among our sites in the Midwest USA, Nepal, and Uganda. The sites in Bolivia and Brazil have little variance in annual temperatures but are more variable in annual precipitation. Sites in Mesoamerica are the most variable in both temperature and precipitation because of considerable variation in elevation. Two study forests in southern Mexico at approximately 2500 $\mathrm{m}$ elevation are cool and fairly dry, whereas a third study forest, in Guatemala, at near 1800 m elevation, is cool and fairly wet. The other study forests, in Guatemala and Honduras, have lower elevations, higher temperatures, and less precipitation.

Both Whittaker's (1975) classification of ecological zones and Holdridge's (1947, 1967) "life zone" method are sometimes criticized for their similarly arbitrary delineation of zonal boundaries. Holdridge's selection of a fairly high mean annual temperature to delineate tropical zones often causes lowland tropical rainforests in the tradewind zones to be omitted from tropical forest categories (Richards 1996). This is likely why our Ugandan sites are plotted as marginal dry tropical forests in the Whittaker diagram (Fig. 1), although such forests have tropical attributes and are typically classified as moist "semi-deciduous" or "semievergreen" lowland rainforest by localized forest classification systems (Lind and Morrison 1974, White 1983, Lovett and Wasser 1993, Richards 1996). 
Fig. 1. Mean annual temperature and precipitation regimes of 42 forests in six regions. Because the climate may be quite similar in several forests within a region, several locations have highly overlapping symbols in this figure.

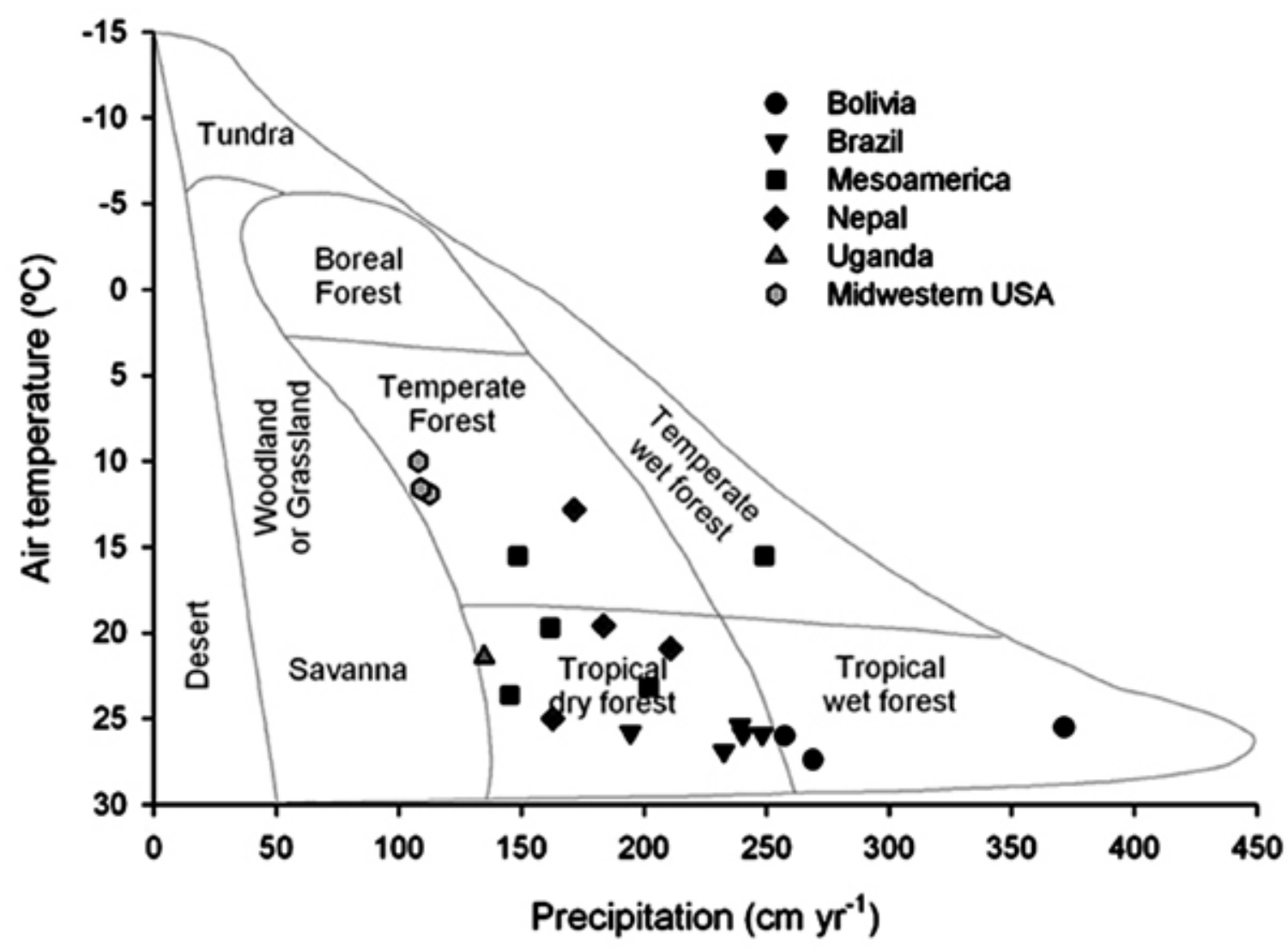

\section{Soils}

Soil characteristics can affect the rates and types of forest growth that occur in particular climatological conditions. Soil nutrient availability, water retention, and soil genesis affect not only the rate of nutrient uptake but also species-specific soil suitability. Acquisition of detailed soils data is a particular challenge for a study such as this. Unfortunately, the Gentry reference data (Phillips and Miller 2002, SALVIAS Project 2003) do not include soil characteristics for each site. The soil information collected as part of the IFRI protocol is rudimentary, in part because the IFRI protocols are designed to be accessible to international researchers with modest technological resources. Existing secondary data sources of soils information for most sites are limited, at coarse spatial scale, and unlikely to represent the true spatial variability of characteristics in the region.

In the absence of detailed soils data, we identified the soil taxonomic orders and suborders for each site using its geographic location and global soils databases (National Resources Cconservation Service (NRCS) 2005, Food and Agricultural 
Organization/United Nations Educational, Scientific, and Cultural Organization (FAO/UNESCO) 2006). Additional information about the characteristics of these soils came from Soil Survey Staff (1975) and Brady and Weil (1999). Although using higherorder soil classes lacks the specificity of soil characteristics present in each site, the use of these groups provides a basic mechanism to evaluate (1) whether the study forest has soil characteristics similar to the reference forest and (2) the range of soil classes represented within each Whittaker (1975) ecological zone.

The soil suborders identified for three reference forests are the same as the study forests within the same ecological zones (Table 1). However, the suborders identified for three other reference forests differ from their associated study forests. In Bolivia, the reference forest has Orthents soil, whereas the study forests have Udepts (NRCS 2005, FAO/ UNESCO 2006). Thus, the soils in these study forests are likely from older parent material than the reference forest. Because Orthents have a shallow soil horizon (common in areas of steep, eroded topography), the reference forest may underestimate the state of mature forests in other soil conditions. In the Nepal sites, the soil suborder of the reference forest is Fluvent, whereas soils of the study forests are Ustepts (NRCS 2005, FAO/UNESCO 2006). Fluvent soils are alluvial Entisols commonly found in floodplains, whereas Usteps are Inceptisols of subhumid climates. The soils of the Brazilian study forests are Udox and Ustults, whereas Aquepts characterize the reference forest (NRCS 2005, FAO/UNESCO 2006). These Brazilian forests are not located in a moisture-limiting environment, so the differences in forest characteristics among the Udox, Ustult, and Aquept soils are likely small.

\section{Forest Conditions Index}

To compare forest conditions among the study forests and the reference forest in each ecological and climatological zone, we developed an index to assess the extent of disturbance (Table 2). This index focuses on mature forests and uses data for trees with $\mathrm{dbh}>10 \mathrm{~cm}$. Four equally weighted ratios are summed for the overall index of disturbance value. The scale ranges linearly from zero (maximum disturbance) to 4.00 (the reference forest). The first ratio is the total basal area of trees in a study forest to the total basal area of trees in the reference forest. The second ratio is the mean dbh of trees in a study forest to the mean dbh of trees in the reference forest. The third ratio is the proportion of tree density to total density, including both trees and saplings, in a given study forest to the proportion of tree density to total density in the reference forest. The fourth ratio is the number of tree species observed in a study forest to the number of tree species observed in the reference forest. Thus, this index produces higher values for forests with large trees (higher mean dbh) that comprise higher proportions of total tree and sapling density and thus results in higher basal area. The fourth ratio produces higher values for study forests with more tree species observed. The species richness ratio indicates how the study forest varies from the reference forest. For some study forests, a species richness that is greater than the reference forest could indicate degradation, high numbers of secondary successional species, or invasive species. In this case, the ratio should be subtracted from the index. However, our study forests did not present these conditions. Fieldwork in the forests is crucial to interpret this ratio.

\section{RESULTS}

\section{Forest Conditions}

Using the forest conditions index, the most disturbed study forest (index $=0.91$ ) is in Nepal. This forest has a total basal area of $10.42 \mathrm{~m}^{2} / \mathrm{ha}$ (tree basal area of only $1.96 \mathrm{~m}^{2} / \mathrm{ha}$ ), is heavily dominated by saplings, and has only 18 observed tree species. Five dry tropical study forests in Guatemala and Honduras have a disturbance index of 2.00 or less relative to their reference forest. These forests are dominated by small pine (Pinus oocarpa) trees and have low basal areas and small numbers of tree species (see Tucker and Southworth 2005 for more details about these forests and their institutions). One dry tropical study forest in eastern Brazil has a disturbance index of 1.86, resulting primarily from low tree density and tree species diversity. Thus, seven of our 36 study forests can be regarded as "degraded" compared with their respective reference forests. Twenty-one study forests have index values ranging from 2.01 to 3.00. These forests show some evidence of degraded forest conditions but also may be experiencing some regrowth of larger trees. 
Table 1. Summary of characteristics of the study and reference forests (00) in each region.

\begin{tabular}{|c|c|c|c|c|c|c|c|c|c|c|}
\hline Country & Forest & Soil Order & $\begin{array}{l}\text { Soil Sub- } \\
\text { order }\end{array}$ & $\begin{array}{l}\text { Total BA } \\
\left(\mathrm{m}^{2} / \mathrm{ha}\right)\end{array}$ & $\begin{array}{l}\text { BA Trees } \\
\left(\mathrm{m}^{2} / \mathrm{ha}\right)\end{array}$ & Primary Dominant & BA & $\begin{array}{l}\text { No. T- } \\
\text { ree Sp- } \\
\text { ecies }\end{array}$ & $\begin{array}{l}\text { Mean Tree } \\
\text { Density }\end{array}$ & $\begin{array}{l}\text { Mean Tree } \\
\text { DBH }(\mathrm{cm})\end{array}$ \\
\hline Bolivia & BO01 & Inceptisols & Udepts & 18.41 & 15.22 & Ficus sp. & 3.15 & 72 & 180 & 24.5 \\
\hline Bolivia & $\mathrm{BO} 02$ & Inceptisols & Udepts & 27.78 & 25.72 & Ficus sp. & 3.98 & 56 & 295 & 24.8 \\
\hline Bolivia & $\mathrm{BO} 03$ & Inceptisols & Udepts & 34.29 & 31.20 & Ficus sp. & 8.44 & 59 & 326 & 26.6 \\
\hline Bolivia & $\mathrm{BO} 04$ & Inceptisols & Udepts & 37.72 & 35.19 & Hura crepitans & 5.35 & 57 & 266 & 28.2 \\
\hline Bolivia & $\mathrm{BO} 00$ & Entisols & Orthents & 51.22 & 46.68 & Oenocarpus sp. & 4.90 & 146 & 210 & 30.7 \\
\hline Brazil & BR01 & Oxisols & Udox & 31.74 & 27.68 & Cenostigma tocantinum & 1.26 & 165 & 440 & 22.6 \\
\hline Brazil & BR02 & Ultisols & Ustults & 24.85 & 20.96 & Guatteria poeppigiana & 4.10 & 61 & 547 & 20.6 \\
\hline Brazil & BR03 & Oxisols & Udox & 36.77 & 28.60 & Apeiba glabra & 5.37 & 39 & 927 & 18.7 \\
\hline Brazil & BR04 & Oxisols & Udox & 34.34 & 30.93 & Eschweilera coriacea & 7.39 & 37 & 180 & 23.3 \\
\hline Brazil & BR00 & Inceptisols & Aquepts & 50.49 & 44.33 & Tapirira sp. & 3.84 & 203 & 950 & 21.8 \\
\hline Guatemala & ME01 & Inceptisols & Udepts & 19.67 & 19.02 & Pinus oocarpa & 10.00 & 7 & 247 & 27.0 \\
\hline Guatemala & ME02 & Inceptisols & Udepts & 26.96 & 23.93 & Pinus oocarpa & 11.11 & 20 & 415 & 23.0 \\
\hline Guatemala & ME03 & Inceptisols & Udepts & 20.63 & 18.25 & Pinus oocarpa & 11.89 & 6 & 272 & 26.0 \\
\hline Guatemala & ME04 & Inceptisols & Udepts & 27.43 & 23.04 & Pinus oocarpa & 9.08 & 24 & 344 & 25.0 \\
\hline Guatemala & ME05 & Inceptisols & Ustepts & 16.37 & 14.50 & Pinus oocarpa & 13.31 & 10 & 329 & 21.0 \\
\hline Guatemala & ME06 & Inceptisols & Ustepts & 41.53 & 37.51 & Liquidambar styraciflua & 10.78 & 24 & 778 & 21.0 \\
\hline Guatemala & ME07 & Inceptisols & Udepts & 24.57 & 24.07 & Pinus oocarpa & 21.13 & 17 & 336 & 26.0 \\
\hline Honduras & ME08 & Inceptisols & Ustepts & 10.13 & 9.24 & Pinus oocarpa & 8.50 & 6 & 210 & 20.0 \\
\hline Honduras & ME09 & Inceptisols & Ustepts & 15.04 & 13.15 & Pinus oocarpa & 12.05 & 9 & 260 & 22.0 \\
\hline Honduras & ME10 & Inceptisols & Ustepts & 25.63 & 21.16 & Pinus oocarpa & 15.86 & 14 & 599 & 19.0 \\
\hline Honduras & ME11 & Inceptisols & Ustepts & 11.72 & 9.22 & Pinus oocarpa & 8.42 & 11 & 254 & 19.0 \\
\hline Mexico & ME12 & Inceptisols & Ustepts & 28.01 & 24.08 & Quercus sp. & 4.10 & 20 & 562 & 22.7 \\
\hline Mexico & ME13 & Inceptisols & Ustepts & 24.44 & 22.25 & Quercus sp. & 7.24 & 20 & 475 & 23.3 \\
\hline Mexico & ME14 & Inceptisols & Ustepts & 37.10 & 32.47 & Quercus sp. & 9.50 & 24 & 591 & 23.4 \\
\hline Mexico & ME00 & Inceptisols & Ustepts & 46.07 & 42.05 & Pinus pseudostrobus & 20.70 & 24 & 510 & 30.1 \\
\hline Nepal & NE01 & Inceptisols & Udepts & 10.42 & 1.96 & Shorea robusta & 1.63 & 18 & 130 & 13.3 \\
\hline
\end{tabular}




\begin{tabular}{|c|c|c|c|c|c|c|c|c|c|c|}
\hline Nepal & $\mathrm{NE} 02$ & Inceptisols & Udepts & 27.57 & 17.81 & Shorea robusta & 12.48 & 36 & 330 & 20.4 \\
\hline Nepal & NE03 & Inceptisols & Udepts & 26.66 & 22.43 & Shorea robusta & 16.73 & 32 & 257 & 28.8 \\
\hline Nepal & NE04 & Inceptisols & Udepts & 29.94 & 24.04 & Shorea robusta & 10.49 & 35 & 347 & 24.2 \\
\hline Nepal & NE05 & Inceptisols & Udepts & 24.70 & 19.59 & Shorea robusta & 6.30 & 41 & 295 & 25.0 \\
\hline Nepal & NE00 & Entisols & Fluvents & 33.34 & 32.46 & Shorea robusta & 15.78 & 43 & 405 & 39.4 \\
\hline Uganda & UG01 & Oxisols & Udox & 19.85 & 16.55 & Pseudospondia macocarpa & 3.13 & 42 & 269 & 24.3 \\
\hline Uganda & UG02 & Oxisols & Udox & 17.95 & 16.95 & Celtis mildbreadii & 2.53 & 49 & 313 & 21.7 \\
\hline Uganda & UG03 & Oxisols & Udox & 29.59 & 27.34 & Tabernmontana holstii & 6.81 & 57 & 365 & 23.8 \\
\hline Uganda & UG00 & Oxisols & Udox & 36.05 & 34.48 & Cedrella odorata & 4.16 & 60 & 384 & 28.2 \\
\hline USA & US01 & Alfisols & Udalfs & 29.21 & 27.48 & Quercus alba & 7.07 & 22 & 307 & 29.3 \\
\hline USA & US02 & Alfisols & Udalfs & 26.02 & 25.01 & Liriodendron tulipifera & 6.87 & 25 & 368 & 26.2 \\
\hline USA & US03 & Alfisols & Udalfs & 30.04 & 28.15 & Quercus alba & 4.93 & 24 & 354 & 28.0 \\
\hline USA & US04 & Alfisols & Udalfs & 30.23 & 28.86 & Liriodendron tulipifera & 6.36 & 25 & 325 & 29.4 \\
\hline USA & US05 & Alfisols & Udalfs & 32.03 & 30.95 & Liriodendron tulipifera & 7.06 & 28 & 326 & 30.1 \\
\hline USA & US06 & Alfisols & Udalfs & 24.27 & 22.48 & Acer saccharum & 2.61 & 28 & 641 & 22.5 \\
\hline USA & USO0 & Alfisols & Udalfs & 49.42 & 47.27 & Fagus grandifolia & 11.86 & 32 & 420 & 33.2 \\
\hline
\end{tabular}

Eight study forests have index values $>3.01$, and three of those-one in the Midwest USA (index value $=3.30$ ), one in Uganda (index value $=3.29$ ), and one in Guatemala (index value $=3.18$ ) - have the highest values (the least disturbance) relative to their reference forests. These study forests have high ratios of basal area and mean dbh of trees, and high tree species diversity relative to their respective reference forests (USA: Parker and Merritt 1994, Gobel and Hix 1996; Uganda: Banana and GombyaSsembajjwe 2000; Guatemala: Gibson et al. 2002, Tucker and Southworth 2005, Tucker et al. 2007). And based on our firsthand observations of these least disturbed forests, we know that they all have some degree of protection from human perturbations due to a combination of relative inaccessibility and local institutional arrangements.

To compare forest conditions across ecological and climatological zones, we plotted the disturbance index values as a function of the PET for each site. Values for the six reference forests are 4.0 and appear at the top of Fig. 2. The annual PET value of each reference forest corresponds reasonably well with the PET values for the study forests in that region with the exception of Nepal, where the PET of the reference forest is higher than for the study forests. The most degraded forests (index value = 2.00 or less) occur in the dry tropics (annual PET values of 800 to $1400 \mathrm{~mm}$ ).

\section{DISCUSSION}

\section{Reference Forests}

The use of reference forests adds opportunities and challenges for cross-ecological comparative analyses. Advantages stem from the role the reference forest plays in establishing baselines for various ecological attributes that are specific to each forest type. Such baselines provide the standard used to transform data across zones that are not 
Table 2. Index of disturbance calculated for each study forest relative to the reference forest in each region. The scale ranges from zero (maximum disturbance) to 4.00 (the reference forest). See text for definitions.

\begin{tabular}{|c|c|c|c|c|c|c|}
\hline Country & Forest & $\begin{array}{c}\text { Tree BA } \\
\text { Ratio }\end{array}$ & $\begin{array}{c}\text { Tree DBH } \\
\text { Ratio }\end{array}$ & Tree Density Ratio & Tree Species Ratio & Index \\
\hline Bolivia & BO01 & 0.33 & 0.80 & 0.43 & 0.49 & 2.05 \\
\hline Bolivia & BO02 & 0.55 & 0.81 & 0.82 & 0.38 & 2.57 \\
\hline Bolivia & $\mathrm{BO} 03$ & 0.67 & 0.87 & 0.66 & 0.40 & 2.60 \\
\hline Bolivia & BO04 & 0.75 & 0.92 & 0.76 & 0.39 & 2.82 \\
\hline Bolivia & BO00 & 1.00 & 1.00 & 1.00 & 1.00 & 4.00 \\
\hline Brazil & BR01 & 0.62 & 0.83 & 0.76 & 0.81 & 3.03 \\
\hline Brazil & BR02 & 0.47 & 0.76 & 0.89 & 0.30 & 2.43 \\
\hline Brazil & BR03 & 0.65 & 0.69 & 0.60 & 0.19 & 2.12 \\
\hline Brazil & BR04 & 0.70 & 0.86 & 0.12 & 0.18 & 1.86 \\
\hline Brazil & BR00 & 1.00 & 1.00 & 1.00 & 1.00 & 4.00 \\
\hline Guatemala & ME01 & 0.45 & 0.90 & 0.95 & 0.29 & 2.59 \\
\hline Guatemala & ME02 & 0.57 & 0.76 & 0.47 & 0.83 & 2.64 \\
\hline Guatemala & ME03 & 0.43 & 0.86 & 0.35 & 0.25 & 1.90 \\
\hline Guatemala & ME04 & 0.55 & 0.83 & 0.26 & 1.00 & 2.63 \\
\hline Guatemala & ME05 & 0.34 & 0.70 & 0.54 & 0.42 & 2.00 \\
\hline Guatemala & ME06 & 0.89 & 0.70 & 0.59 & 1.00 & 3.18 \\
\hline Guatemala & ME07 & 0.57 & 0.86 & 0.86 & 0.71 & 3.01 \\
\hline Honduras & ME08 & 0.22 & 0.66 & 0.75 & 0.25 & 1.88 \\
\hline Honduras & ME09 & 0.31 & 0.73 & 0.37 & 0.38 & 1.79 \\
\hline Honduras & ME10 & 0.50 & 0.63 & 0.40 & 0.58 & 2.11 \\
\hline Honduras & ME11 & 0.22 & 0.63 & 0.26 & 0.46 & 1.57 \\
\hline Mexico & ME12 & 0.57 & 0.75 & 0.52 & 0.83 & 2.68 \\
\hline Mexico & ME13 & 0.53 & 0.77 & 0.68 & 0.83 & 2.82 \\
\hline Mexico & ME14 & 0.77 & 0.78 & 0.43 & 1.00 & 2.98 \\
\hline Mexico & ME00 & 1.00 & 1.00 & 1.00 & 1.00 & 4.00 \\
\hline Nepal & NE01 & 0.06 & 0.34 & 0.09 & 0.42 & 0.91 \\
\hline
\end{tabular}




\begin{tabular}{|c|c|c|c|c|c|c|}
\hline Nepal & NE02 & 0.55 & 0.52 & 0.16 & 0.84 & 2.06 \\
\hline Nepal & NE03 & 0.69 & 0.73 & 0.23 & 0.74 & 2.40 \\
\hline Nepal & NE04 & 0.74 & 0.61 & 0.20 & 0.81 & 2.36 \\
\hline Nepal & NE05 & 0.60 & 0.64 & 0.22 & 0.95 & 2.42 \\
\hline Nepal & NE00 & 1.00 & 1.00 & 1.00 & 1.00 & 4.00 \\
\hline Uganda & UG01 & 0.48 & 0.86 & 0.44 & 0.70 & 2.48 \\
\hline Uganda & UG02 & 0.49 & 0.77 & 0.93 & 0.82 & 3.01 \\
\hline Uganda & UG03 & 0.79 & 0.85 & 0.70 & 0.95 & 3.29 \\
\hline Uganda & UG00 & 1.00 & 1.00 & 1.00 & 1.00 & 4.00 \\
\hline USA & US01 & 0.64 & 0.91 & 0.43 & 0.69 & 2.66 \\
\hline USA & US02 & 0.58 & 0.81 & 0.90 & 0.78 & 3.08 \\
\hline USA & US03 & 0.66 & 0.87 & 0.71 & 0.75 & 2.99 \\
\hline USA & US04 & 0.67 & 0.91 & 0.67 & 0.78 & 3.04 \\
\hline USA & US05 & 0.72 & 0.94 & 0.77 & 0.88 & 3.30 \\
\hline USA & US06 & 0.52 & 0.70 & 0.71 & 0.88 & 2.81 \\
\hline USA & US00 & 1.00 & 1.00 & 1.00 & 1.00 & 4.00 \\
\hline
\end{tabular}

directly comparable to data that are. In our study, these baselines enable the calculation of indices that represent degrees of deviation of study forests from the reference forest within each zone, which are then comparable across ecological zones and forest types. As researchers continue to elaborate restoration methods for forests and other ecosystems, reference data also provide a benchmark toward which restoration efforts can be targeted.

A critical contribution of the reference forest approach is that it can help distinguish outcomes that may appear similar but result from contrasting processes or biophysical contexts. For example, it is possible that two forests appear to be in similar states of degradation, yet it would be problematic to assume that both forests lack effective institutional arrangements. Degraded forests in dry, cool climates typically recover slowly even when strong and effective institutions have been developed for their management. By contrast, degraded forests in moist, hot climates can recover from impacts rapidly even when institutional arrangements are deficient.

Moreover, the use of reference forests is appropriate when outcomes appear dissimilar, but result from similar processes. Different geographic regions may exhibit dissimilar rates of recovery from similar human-induced disturbances. Studies estimating forest structural recovery time after selective logging can range widely within a similar climatic zone. For example, a wet tropical forest in South America recovers in 15-20 years (Nicotra et al. 1999) whereas a wet tropical forest in East Africa recovers in 50 years (Plumptre 1996). Such disparities may arise as a result of divergent ecological recovery response mechanisms engendered by differing regimes of large-scale natural disturbance over evolutionary time (Chapman et al. 1999). African tropical forests have a near absence or reduced intensity and frequency of large-scale natural disturbances such as hurricanes and 
Fig. 2. Estimate of relative human disturbance. The disturbance index values of the study forests relative to their corresponding reference forest plotted as a function of the PET for each site. Values for the six reference forests are equal to 4.0 and appear at the top of the figure.

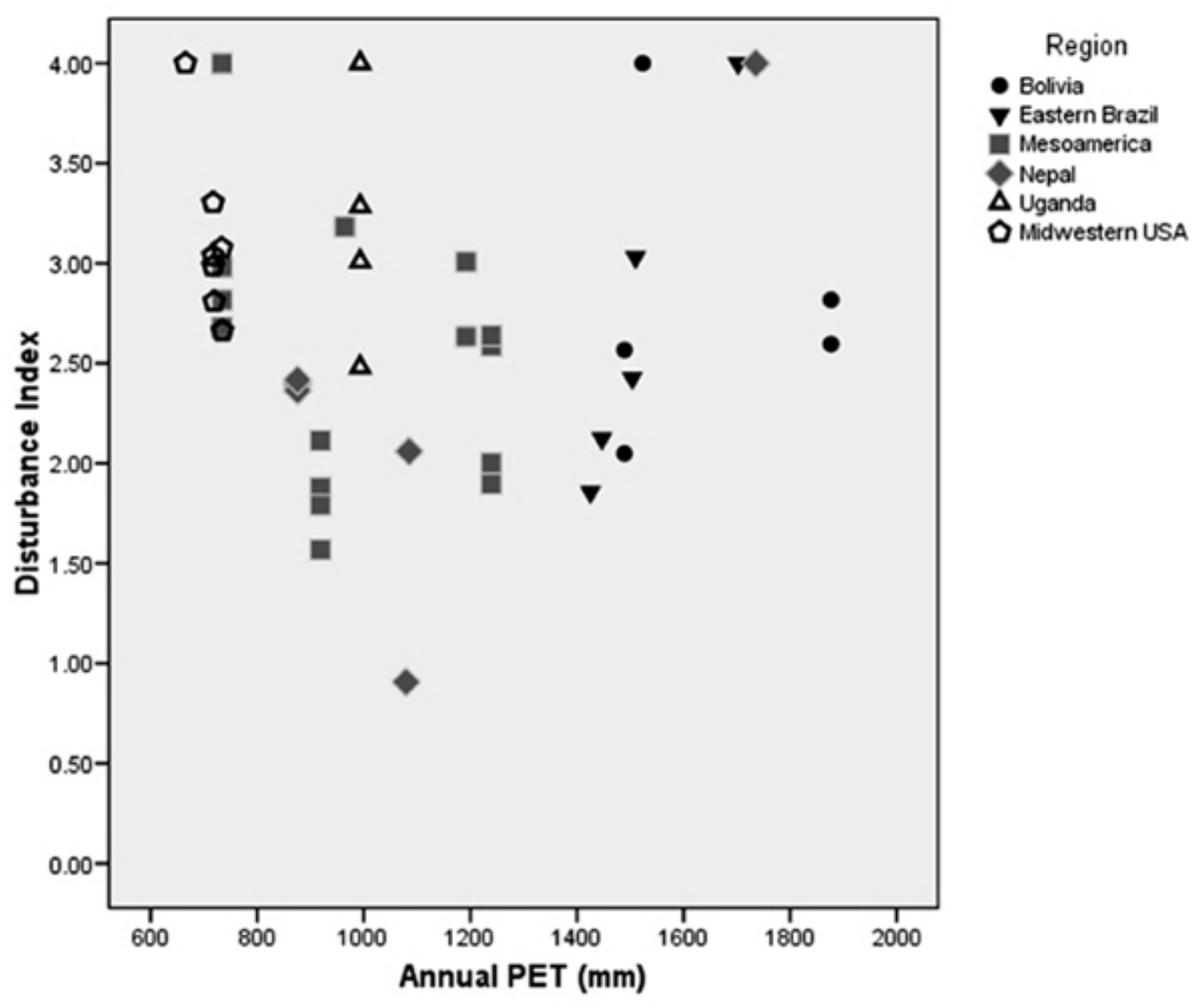


earthquakes, compared with Central and South America and Southeast Asia (Richards 1996, Chapman et al. 1999).

Our use of reference forests is similar to the "reference ecosystem" concept currently being used by the Institute for Environment and Sustainability of the European Commission for a classification and assessment of "lake conditions" of all freshwater lakes in the 25 countries of the European Union (EU) (Heiskanen et al. 2004, van de Bund et al. 2004). Each lake is placed within a category using a typology of 17 lake types occurring in the EU, and at least one reference lake is identified for each type using several chemical and biological variables for pristine or only slightly modified conditions. Then an assessment index is calculated for each lake relative to the reference lake within that lake type.

The primary challenge to using reference forests stems from the degree to which study forestreference forest pairs are accurate matches for comparison. Although it is fairly straightforward to find forest pairs with similar edaphic and biophysical properties at a fairly coarse level, the level of variation of such properties at finer spatial scales is typically complex. It is, therefore, difficult to find perfect comparators across sites, even when biophysical factors appear similar. As a result, it is not always possible to identify reference forests that are closely representative of biophysical conditions in the study forests. Moreover, the use of reference forest data collected by different researchers presents the potential for inconsistencies in parameter estimates due to methodological differences in sampling techniques. Basal area measures, for example, can result in under- or overestimates if the plot size does not adequately capture local, spatial heterogeneity of tree species. Even if plot sizes are adequate, basal area measurements for a given forest may vary with differences in methodology, such as plot geometry, smallest tree diameter measured, and sampling intensity (Alder and Synnott 1992). Another challenge is the varying levels of knowledge about disturbance levels, particularly when data gathering relies on interviews with key informants. We are confident in the integrity of the IFRI and reference forest data sampling methods, even though we recognize that a few variations exist between the two datasets. Our familiarity with the study forests and the biophysical conditions of each region in this research gives us a frame of reference to confirm that the datasets are valid for comparison.

\section{Forest Conditions Index}

Using four ratios of forest metrics and the resulting index value between a study forest and its reference forest, we estimate the degree to which human activities have impacted a study forest, at least in terms of trees. These ratios and the index can be used in specific applications as a basis for evaluating and comparing forest conditions and change across ecological zones. First, and of particular interest, this basis for comparison will enable researchers to assess management and conservation interventions for large samples of forests across regions. Second, the index can provide a baseline assessment of forest conditions for areas identified for specific types of conservation interventions. Thereafter, the success of the intervention can be evaluated in part by the direction of change in the baseline values. Third, this approach can be used to compare forest management and conservation methods across different forest types, with the potential of identifying which methods appear to be most effective regardless of the biophysical contrasts between forests. Fourth, because biophysical differences can be controlled in an analysis, it is feasible to rigorously and systematically explore the extent to which socioeconomic, institutional, and political variables shape forest conditions and transformations.

Having accounted for known anomalies, we infer that the difference between the condition of a reference forest and a study forest in this research relates principally to human interventions. The fact that we did not learn of any recent natural disturbances in these forests is a prerequisite for making such an inference. Data collected from ethnographic fieldwork and forest mensuration, which we discuss elsewhere (e.g., Evans et al. 2001, Evans and Kelley 2004, Tucker 2004a, Randolph et al. 2005, Tucker et al. 2007), support the thesis that human activities in these forests have made significant impacts. Although variation exists across the study forests, typical activities include livestock grazing, fuelwood collection, charcoal production, and selective logging. Forest mensuration and observations frequently noted tree stumps, evidence of grazing, and remains of cut trees. The forests that exist in the Midwest USA are primarily successional forests that have regrown when areas previously used for agricultural production were abandoned (Evans et al. 2001). For the Mesoamerican study forests with the lowest index values, the documented history of human 
transformations extends back several hundred years to the colonial period. Archaeological remains in one of the sites indicate prehispanic settlements and high likelihood of associated forest perturbations (Tucker 1999, in press).

One Mesoamerican forest with a high index value (3.18) represents a unique case within the regional sample and our study. We know that it is more moist and higher in elevation than the other study forests in the region from our field data (Tucker et al. 2007). Moreover, it is a cloud forest rather than a pine-oak (Quercus spp.) forest. Due to the topographic complexity of the region, the global dataset does not indicate these distinctions. Based on our field data and reference to local meteorological data, we made appropriate adjustments to the temperature and precipitation data provided by the global dataset. The anomaly of this cloud forest not only demonstrates a risk of complete reliance on global datasets, but also illustrates the utility of fieldwork. We were unable to discover data from another cloud forest in Mesoamerica that could serve as a true reference. This example also illustrates one of the shortcomings of this approach: it is not always possible to find a reference forest that is similar to a study forest.

We recognize that a forest may be profoundly transformed by human interventions yet have forest metrics (e.g., basal area of trees) that appear similar to a reference forest. For example, introduction of certain exotic tree species could increase basal area (e.g., fast-growing eucalyptus) but undermine the natural vegetation composition represented by a reference forest. Similarly, agroforestry projects could profoundly change a forest. These points indicate the importance of collecting locally relevant data in order to conduct a competent analysis. Even given these caveats, our approach provides a useful tool that can contribute to more rigorous comparative analyses of forest conservation. In related research, we show that the use of reference forests increased our ability to distinguish certain institutional impacts from biophysical factors that shape forest conditions (Tucker et al. 2007).

We would like to expand this study to include a wider range of forest types; however, doing so depends on the availability of comparable forest data. Throughout the world, well-trained foresters use a similar set of methods to collect forest data, but many of these data remain inaccessible to the public or unavailable for use in comparative analysis. If comparative analysis of global forest conditions is to be conducted, it is imperative that data be made publicly available. Only then will analyses be able to encompass a more inclusive range of forest types and states of conservation. Gentry's commitment to rigorous data collection and public dissemination (Phillips and Miller 2002, SALVIAS Project 2003) offers an example worthy of emulation.

\section{CONCLUSION}

To understand the consequences of human modifications on forest ecosystems it is necessary to (1) understand the biological and physical factors that influence the nature and composition of the forest and (2) make quantitative measurements of variables describing forest conditions that are useful for comparative analysis. Studies of how human behaviors and institutions influence forest ecosystems conducted in the absence of considerable knowledge of those ecosystems has limited usefulness beyond a general level of analysis.

Our study presents a means of developing a quantitative assessment of the differences in forest conditions by comparing reference forests with human-influenced forests. By proposing a quantitative approach for comparing forests across differing vegetative, edaphic, and climatic conditions, this study suggests a way to distinguish human and institutional impacts from the underlying biophysical characteristics. The application of quantitative measures of difference has the potential to allow more specific assessments of the outcomes of forest management strategies by distinguishing biological and human components of human-environment systems (Persha 2005). With better quantitative data, it may be possible to refine forest management policies and institutions to better fit site-specific human impacts and associated biophysical conditions. Our method also provides a potentially useful indicator of forest transformations in comparative studies. The use of quantitative data in this method lends it greater robustness than other methods to compare forest outcomes across biomes, which depend upon qualitative assessments and observations to assess the outcomes of institutional arrangements (e.g., Bruner et al. 2001, Gibson et al. 2005, Hayes 2006). 
This method faces a further, more fundamental challenge: few forests in relatively well-conserved conditions endure. Without some baseline provided by minimally impacted reference forests, it is difficult to assess the changes that human activities and institutions have wrought. In the absence of suitable reference forests, it is problematic to assess forest conditions through comparison among forests that have been and continue to be altered significantly by humans. To assess forest conditions and changes objectively, we need to have research strategies based on rigorous data collected in wellpreserved forests. The preservation of minimally impacted forests thus carries ramifications in addition to the conservation of biodiversity, environmental services, or aesthetic value: it is a key to scientific analysis of local and global forest change.

Responses to this article can be read online at:

http://www.ecologyandsociety.org/voll3/iss 1/art4/responses/

\section{Acknowledgments:}

We acknowledge support for this research provided by the National Science Foundation (NSF) to the Center for the Study of Institutions, Population, and Environmental Change (CIPEC), the NSF Human and Social Dynamics Program (grant BCS0624178), and the United States Agency for International Development through its SANREM-CRSP program. The authors express gratitude to CIPEC, the International Forestry Resources and Institutions Research Program, and the Workshop in Political Theory and Policy Analysis for the opportunities they provide for genuinely interdisciplinary research. The University of Arizona, in cooperation with the Center for Applied Biodiversity Science at Conservation International, generously provided Alwyn Gentry's data. We thank Burnell Fischer and two anonymous reviewers for valuable comments.

\section{LITERATURE CITED}

Aber, J. D., and J. M. Melillo. 2001. Terrestrial ecosystems. Second edition. Harcourt Academic Press, San Diego, California, USA.
Alcorn, J. B. 1990. Indigenous agroforestry strategies meeting farmers' needs. Pages 141-151 in A. B. Anderson, editor. Alternatives to deforestation: steps to sustainable use of the Amazon rain forest. Columbia University Press, New York, New York, USA.

Alder, D., and T. J. Synnott. 1992. Permanent sample plot techniques for mixed tropical forest. Tropical Forestry Paper No. 25. Oxford Forestry Institute, Oxford, UK.

Andersson, K. 2003. What motivates municipal governments? Uncovering the institutional incentives for municipal governance of forest resources in Bolivia. Journal of Environmental Development 12:5-27.

Andersson, K., and C. C. Gibson. 2007. Decentralized governance and environmental change: how local institutions moderate deforestation in Bolivia. Journal of Policy Analysis and Management 26(1):99-123.

Andersson, K., and D. Pacheco. 2006. Turning to forestry for a way out of poverty: is formalizing property rights enough? Pages 195-211 in B. GuhaKhasnobis, R. Kanbur, and E. Ostrom, editors. Linking the formal and informal economy: concepts and policies. Oxford University Press, Oxford, UK.

Asbjornsen, H., L. A. Brudvig, C. M. Mabry, C. W. Evans, and H. M. Karnitz. 2005. Defining reference information for restoring ecologically rare tallgrass oak savannas in the midwestern United States. Journal of Forestry 103(7):345-350.

Banana, A. Y., and W. Gombya-Ssembajjwe. 2000. Successful forest management: the importance of security of tenure and rule enforcement in Ugandan forests. Pages 87-98 in C. C. Gibson, M. A. McKean, and E. Ostrom, editors. People and forests: communities, institutions, and governance. The MIT Press, Cambridge, Massachusetts, USA.

Brady, N. C., and R. R. Weil. 1999. The nature and property of soils. Twelfth edition. Prentice-Hall, Upper Saddle River, New Jersey, USA.

Bromley, D., editor. 1992. Making the commons work: theory, practice and policy. Institute for Contemporary Studies Press, San Francisco, 
California, USA.

Brosius, P., A. Tsing, and C. Zerner, editors. 2005. Communities and conservation: histories and policies of community-based natural resource management. Altamira Press, Walnut Creek, California, USA.

Bruner, A. G., R. E. Gullison, R. E. Rice, and G. A. B. Da Fonseca. 2001. Effectiveness of parks in protecting tropical biodiversity. Science 291:125128.

Bugmann, H. 2001. A comparative analysis of forest dynamics in the Swiss Alps and the Colorado Front Range. Forest Ecology and Management 145:43-55.

Chapman, C. A., L. J. Chapman, L. Kaufman, and A. E. Zanne. 1999. Potential causes of arrested succession in Kibale National Park, Uganda: growth and mortality of seedlings. African Journal of Ecology 37:81-92.

Dietz, T., E. Ostrom, and P. C. Stern. 2003. The struggle to govern the commons. Science 302:19071912.

Evans, T. P., G. M. Green, and L. Carlson. 2001. Multi-scale analysis of land-cover composition and landscape management of public and private lands in Indiana. Pages 271-287 in A. C. Millington, S. J. Walsh, and P. E. Osborne, editors. GIS and remote sensing applications in biogeography and ecology. Kluwer, Boston, Massachusetts, USA.

Evans, T. P., and H. Kelley. 2004. Multi-scale analysis of a household level agent-based model of landcover change. Journal of Environmental Management 72(1-2):57-72.

Ferretti, M., R. Bussotti, E. Cenni, and A. Cozzi. 1999. Implementation of quality assurance procedures in the Italian programs of forest condition monitoring. Water, Air, and Soil Pollution 116:371-376.

Food and Agriculture Organization/United Nations Educational, Scientific, and Cultural Organization (FAO/UNESCO). 2006. Digital soil map of the world and derived soil properties. CDROM Ver. 1. FAO, Rome, Italy.

Frelich, L. E., M. W. Cornett, and M. A. White.
2005. Controls and reference conditions in forestry: the role of old-growth and retrospective studies. Journal of Forestry 103(7):339-344.

Gentry, A. H. 1992. Tropical forest biodiversitydistributional patterns and their conservational significance. Oikos 63(1):19-28.

Gibson, C. C., F. E. Lehoucq, and J. T. Williams. 2002. Does privatization protect natural resources? Property rights and forests in Guatemala. Social Science Quarterly 83:206-225.

Gibson, C. C., M. A. McKean, and E. Ostrom, editors. 2000. People and forests: communities, institutions, and governance. The MIT Press, Cambridge, Massachusetts, USA.

Gibson, C. C., J. Williams, and E. Ostrom. 2005. Local enforcement and better forests. World Development 33(2):273-284.

Gobel, P. C., and D. M. Hix. 1996. Development of mixed oak forests in southeastern Ohio: a comparison of second-growth and old-growth forests. Forest Ecology and Management 84:1-21.

Gorte, R. W. 2002. Forest ecosystem health: an overview. Pages 243-250 in A. S. Goudie, editor. Encyclopedia of global change: environmental change and human society. Oxford University Press, Oxford, UK.

Haenn, N. 2005. Fields of power, forests of discontent: culture, conservation and the state in Mexico. University of Arizona Press, Tucson, Arizona, USA.

Hayes, T. 2006. Parks, people, and forest protection: an institutional assessment of the effectiveness of protected areas. World Development 34(12):20642075.

Heiskanen, A.-S., W. van de Bund, A. C. Cardoso, and P. Noges. 2004. Ecological quality assessment in the EU water framework directive-a new approach for protection of aquatic ecosystem. Pages 211-223 in P. Wassmann and K. Olli, editors. Drainage basin nutrient inputs and eutrophication: an integrated approach. University of Troms $\varnothing$, Troms $\varnothing$, Norway. (online) URL: http://lepo.it.da.ut. ee./ olli/eutr/Eutrophication.pdf (January 2005 version). 
Hockings, M. 2003. Systems for assessing the effectiveness of management in protected areas. Bioscience 53:823-832.

Holdridge, L. R. 1947. Determination of world plant formations from simple climatic data. Science 105:367-368.

Holdridge, L. R. 1967. Life zone ecology. Revised edition. Tropical Science Center, San José, Costa Rica.

IUCN/World Conservation Union. 1994. Guidelines for protected area management categories. IUCN and the World Conservation Monitoring Centre, Gland, Switzerland. (online) URL: www.iucn.org

Kenefic, L. S., A. S. White, A. R. Cutko, and S. Fraver. 2005. Reference stands for silvicultural research: a Maine perspective. Journal of Forestry 103(7):363-367.

Kobayashi, S. 2004. Landscape rehabilitation of degraded tropical forest ecosystems: case study of the CIFOR/Japan project in Indonesia and Peru. Forest Ecology and Management 201:13-22.

Kubin, E., H. Lippo, and J. Poikolainen. 2000. Heavy metal loading. Pages 60-71 in E. Malkonen, editor. Forest condition in a changing environment -the Finnish case. Kluwer, Dordrecht, The Netherlands.

Lawesson, J. E., G. de Blust, C. Grashof, L. Firbank, O. Honnay, M. Hermy, P. Hobitz, and L. M. Jensen. 1998. Species diversity and arearelationships in Danish beech forests. Forest Ecology and Management 106:235-245.

Lind, E. M., and M. E. S. Morrison. 1974. East African vegetation. Longman, London, UK.

Loucks, O. L. 1992. Forest response research in NAPAP: potentially successful linkage of policy and science. Ecological Applications 2:117-123.

Lovett, J. C., and S. K. Wasser. 1993. Biogeography and ecology of the rain forests of East Africa. Cambridge University Press, Cambridge, UK.

Lundquist, J. E., and J. S. Beatty. 1999. A conceptual model for defining and assessing condition of forest stands. Environmental Management 23:519-525.

Mather, J. R. 1978. The climatic water balance in environmental analysis. Heath, Lexington, Massachusetts, USA.

McClenahen, J. R., and D. B. Houston. 1998. Comparative age structure of a relict prairie transition forest and indigenous forest in southeastern Ohio, USA. Forest Ecology and Management 112:31-40.

McLaughlin, S., and K. E. Percy. 1999. Forest health in North America: some perspectives on actual and potential roles of climate and air pollution. Water, Air, and Soil Pollution 116:151197.

Miller, C., and D. L. Urban. 2000. Modeling the effects of fire management alternatives on Sierra Nevada mixed-conifer forests. Ecological Applications 10:85-94.

Natural Resources Conservation Service (NRCS). 2005. Soil series classification database. NRCS, U.S. Department of Agriculture, Washington, D.C., USA. (online) URL: http://soils.usda.gov/technical/ classification/scfile/index.html.

Ni, J. 2004. Forest productivity of the Altay and Tianshan mountains in the dryland, northwestern China. Forest Ecology and Management 202:13-22.

Nicotra, A. B., R. L. Chazdon, and S. V. B. Iriarte. 1999. Spatial heterogeneity of light and woody seedling regeneration in tropical wet forests. Ecology 80:1908-1926.

Nordlund, G. 2000. Emissions, air quality and acidifying deposition. Pages 49-59 in E. Malkonen, editor. Forest condition in a changing environment -the Finnish case. Kluwer, Dordrecht, The Netherlands.

Ostrom, E. 2005. Understanding institutional diversity. Princeton Universtiy Press, Princeton, New Jersey, USA.

Ostrom, E., T. Dietz, N. Dolšak, P. Stern, S. Stonich, and E. Weber, editors. 2002. The drama of the commons. National Academies Press, Washington, D.C., USA. 
Ostrom, E., and M. Wertime. 2000. International forestry resources and institutions research strategy. Pages 243-268 in C. C. Gibson, M. A. McKean, and E. Ostrom, editors. People and forests: communities, institutions, and governance. The MIT Press, Cambridge, Massachusetts, USA.

Parker, G. R., and C. Merritt. 1994. The central region. Pages 129-172 in J. W. Barrett, editor. Regional silviculture of the United States. Third edition. Wiley, New York, New York, USA.

Penman, H. L. 1948. Natural evaporation from open water, bare soil and grass. Proceedings of the Royal Society of London. Series A, Mathematical and Physical Sciences 193:120-145.

Persha, L. 2005. Monitoring changes in forest condition in collaboratively managed forests: an analysis of scored vs. measured data. Workshop Working Paper No. W04I-22. Workshop on Political Theory and Policy Analysis, Indiana University, Bloomington, Indiana, USA.

Persha, L., K. P. Andersson, T. P. Evans, J. C. Randolph, and C. M. Tucker. 2005. Methods for assessing forest conditions: the complementarity of quantitative and qualitative approaches. CIPEC Working Paper No. CWP-05-05. Center for the Study of Institutions, Population, and Environmental Change (CIPEC), Indiana University, Bloomington, Indiana, USA.

Phillips, A. 2004. Editorial. Parks 14(3):1.

Phillips, O. L., P. Hall, A. H. Gentry, S. A. Sawyer, and R. Vasquez. 1994. Dynamics and species richness of tropical rain-forests. Proceedings of the National Academy of Sciences of the United States of America 91:2805-2809.

Phillips, O., and J. S. Miller. 2002. Global patterns of plant diversity: Alwyn H. Gentry's forest transect data set. Missouri Botanical Garden Press, St. Louis, Missouri, USA.

Plumptre, A. 1996. Changes following 60 years of selective timber harvesting in the Budongo Forest Reserve, Uganda. Forest Ecology and Management 89(1-3):101-113.

Randolph, J. C., G. M. Green, J. Belmont, T. Burcsu, and D. Welch. 2005. Forest ecosystems and the human dimensions. Pages 61-80 in E. F.
Moran and E. Ostrom, editors. Seeing the forest and the trees: human-environment interactions in forest ecosystems. The MIT Press, Cambridge, Massachusetts, USA.

Reams, G. A., and C. E. Peterson, Jr. 1992. Evaluating changes in forest condition potentially related to acidic deposition: an example using red spruce. Forest Ecology and Management 51:5-16.

Richards, P. W. 1996. The tropical rain forest: an ecological study. Cambridge University Press, Cambridge, UK.

Riitters, K. H., B. E. Law, R. C. Kucera, A. L. Gallant, R. L. Develice, and C. J. Palmer. 1992. A selection of forest condition indicators for monitoring. Environmental Monitoring and Assessment 20:21-33.

Saterson, K.A., N. L. Christensen, R. B. Jackson, R. A. Kramer, S. L. Pimm, M. D. Smith, and J. B. Wiener. 2004. Disconnects in evaluating the relative effectiveness of conservation strategies. Conservation Biology 18(3):597-599.

Skelly, J. M. 1989. Forest decline versus tree decline - the pathological considerations. Environmental Monitoring and Assessment 12:23-27.

Spatial Analysis of Local Vegetation Inventories Across Scales (SALVIAS) Project. 2003. A collaborative project based at University of Arizona (Tucson), in cooperation with the Center for Applied Biodiversity Science at Conservation International, Washington, D.C., USA. Gentry's data published by Missouri Botanical Garden. (online) URL: http://www.salvias.net/pages/databa se info.php (membership required).

Soil Survey Staff. 1975. Soil taxonomy: a basic system of soil classification for making and interpreting soil surveys. Natural Resources Conservation Service, U.S. Department of Agriculture, Washington, D.C., USA.

Thornthwaite, C. W. 1948. An approach toward a rational classification of climate. Geographical Review 38:55-94.

Thornthwaite, C. W., and J. R. Mather. 1955. The water balance. Publications in Climatology VIII:1. Monograph series. Center for Climatic Research, University of Delaware, Newark, Delaware, USA. 
Thornthwaite, C. W., and J. R. Mather. 1957. Instructions and tables for computing potential evapotranspiration and the water balance. Publications in Climatology X:3. Monograph series. Center for Climatic Research, University of Delaware, Newark, Delaware, USA.

Toledo, V. M. 2001. Indigenous peoples, biodiversity and. Pages 451-463 in S. Levin, editor, Encyclopedia of biodiversity. Volume 3. Academic Press, San Diego, California, USA.

Tucker, C. M. 1999. Private vs. communal forests: forest conditions and tenure in a Honduran community. Human Ecology 27:201-230.

Tucker, C. M. 2004a. Aiming for sustainable community forest management: the experiences of two communities in Mexico and Honduras. Pages 178-199 in D. Zarin, J. Alavalapati, F. E. Putz, and M. C. Schmink, editors. Working forests in the tropics: conservation through sustainable management? Columbia University Press, New York, New York, USA.

Tucker, C. M. 2004b. Community institutions and forest management in Mexico's Monarch Butterfly Reserve. Society and Natural Resources 17(7):569587.

Tucker, C. M. In press. Changing forests: collective action, common property, and coffee in Honduras. Springer, Dordrecht, the Netherlands.

Tucker, C. M., and E. Ostrom. 2005. Institutional analysis in multidisciplinary research on human dimensions of global environmental change. Pages 81-103 in E. F. Moran and E. Ostrom, editors. Seeing the forest and the trees: human-environment interactions in forest ecosystems. The MIT Press, Cambridge, Massachusetts, USA.

Tucker, C. M., J. C. Randolph, and E. Castellanos. 2007. Institutions, biophysical factors and history: an integrative analysis of private and common property forests in Guatemala and Honduras. Human Ecology 35(3):259-274.

Tucker, C. M., and J. Southworth. 2005. Processes of forest change at the local and landscape levels in Honduras and Guatemala. Pages 253-277 in E. F. Moran and E. Ostrom, editors. Seeing the forest and the trees: human-environment interactions in forest ecosystems. The MIT Press, Cambridge, Massachusetts, USA.

Uuttera, J., M. Maltamo, and K. Kuusela. 1996. Impact of forest management history on the state of forests in relation to natural forest succession: comparative study, North Karelia, Finland vs. Republic of Karelia, Russian Federation. Forest Ecology and Management 83:71-85.

Uuttera, J., T. Tokola, and M. Maltamo. 2000. Difference in the structure of primary and managed forests in East Kalimantan, Indonesia. Forest Ecology and Management 129:63-74.

van de Bund, W., P. Pollard, U. Irmer, P.-J. Martinez, J.-G. Wasson, G. Ofenboeck, A. Buffagni, K. Nygaard, J. Ortiz-Casas, M. Toro, and A.-S. Heiskanen. 2004. Guidance on the intercalibration process. Guidance document ((online) URL: http://forum.europa.eu.int/Members/ irc/env/wfd/library?l=/working groups/

ecological status/1sworkingsgroup/meeting octob er 2004\&vm=detailed \&sb=Title (membership required)) for the Common implementation strategy for the water framework directive (2000/60/EC). (online) URL: http://ec.europa.eu/environment/water/ water-framework/objectives/pdf/strategy3.pdf.

Walters, C. 1997. Challenges in adpative management of riparian and coastal ecosystems. Conservation Ecology 1(2):1. (online) URL: http:// www.ecologyandsociety.org/vol1/iss2/art1/.

White, F. 1983. Vegetation of Africa: a descriptive memoir to accompany the UNESCO/AETFAT/ UNSO vegetation map of Africa. United Nations Educational, Scientific, and Cultural Organization (UNESCO), Paris, France.

Whitford, H. N. 1901. The genetic development of the forests of northern Michigan: a study in physiographic ecology. Botanical Gazette 31:289325.

Whittaker, R. H. 1975. Communities and ecosystems. Second edition. Macmillan, New York, New York, USA.

Williams, M. 2003. Deforesting the earth: from prehistory to global crisis. University of Chicago Press, Chicago, Illinois, USA.

Willmott, C. J., and J. J. Feddema. 1992. A more 
rational climatic moisture index. Professional Geographer 44:84-88.

Willmott, C. J., and K. Matsuura. 1995. Smart interpolation of annually averaged air temperature in the United States. Journal of Applied Meteorology 34(12):2577-2586. (online) URL: http://ams.allenp ress.com/archive/1520-0450/34/12/pdf/

i1520-0450-34-12-2577.pdf.

Willmott, C. J., and K. Matsuura. 2004. Terrestrial air temperature and precipitation: monthly and annual time series (1950-1999). Version 1.02. (online) URL: http://climate.geog.udel. edu/ climate/html pages/download.html\#ghen T P2

Willmott, C. J., and S. M. Robeson. 1995. Climatologically aided interpolation of terrestrial air temperature. International Journal of Climatology 15:221-229.

Young, O. R. 2002. The institutional dimensions of environmental change. The MIT Press, Cambridge, Massachusetts, USA. 